\title{
Peritoneal infections in patients on long-term peritoneal dialysis before and after human cadaveric renal transplantation
}

\author{
D. A. LEIGH ${ }^{1}$ \\ From the Department of Bacteriology, The Wright-Fleming Institute, \\ St Mary's Hospital Medical School, London
}

SYNOPSIS Long-term peritoneal dialysis was carried out on 38 patients awaiting human cadaveric renal transplantation. Fifty-eight per cent of patients developed infection before transplantation and $41 \%$ of those requiring dialysis after transplantation became infected.

Infection did not usually occur before the third day of dialysis and $26 \%$ of patients developed their first episode of infection in the first week. Almost $50 \%$ of patients had only a single episode of infection.

The overall rate of infection per 100 patient days of dialysis was 1.23 before transplantation and $4 \cdot 17$ after transplantation.

The commonest infecting organisms were Staph aureus and Staph albus and these organisms were frequently isolated from the skin around the dialysis catheter before the infection occurred. Gramnegative infections were more commonly seen after transplantation.

Sixty-five per cent of the infections responded to a single course of antibiotic therapy administered in the dialysis fluid. After transplantation Gram-negative infections were usually associated with severe complications and were a major cause of death.

Peritoneal dialysis is a convenient way of maintaining patients with chronic renal failure before human cadaveric renal transplantation, and infection, although common is not inevitable, provided precautions are taken to ensure that the dialysis procedure is carried out using aseptic techniques and prophylactic therapy is applied to the skin around the dialysis catheter.

Peritoneal dialysis has been used for many years in the short-term treatment of acute renal failure (Maxwell, Rockney, Kleeman, and Twiss, 1959; Burns, Henderson, Hager, and Merrill, 1962). The use of prolonged periods of dialysis has usually been complicated by the development of infection (Boen, Mion, Curtis, and Shilipeter, 1964; Lasker, Shalhoub, Habibe, and Passarotti, 1965; Montgomerie, Kalmanson, and Guze, 1968) and this has limited its value in the management of chronic renal failure especially in patients awaiting renal transplantation. Cohen and Percival (1968) found that only three out of 27 patients dialysed for periods of more than two months remained free of infection.

This paper reports the incidence of peritoneal infection in patients on long-term dialysis before

'Present address: Wycombe General Hospital, High Wycombe, Bucks. Received for publication 19 December 1968. human cadaveric renal transplantation and in patients with acute tubular necrosis following transplantation. The source of the infection and the results of treatment using intraperitoneal administration of antibiotics are presented and discussed.

\section{THE PATIENTS}

Between October 1966 and March 1968, 38 patients (22 women and $16 \mathrm{men}$ ) were maintained on peritoneal dialysis while awaiting renal transplantation (Table I). Thirty-one of these patients were subsequently given renal transplants but in five the donor kidney had to be removed after a few days because of haemorrhage or thrombosis at the vascular anastomosis. Twenty-two patients required dialysis after renal transplantation and seven patients have not yet been transplanted.

The length of time that dialysis was carried out before transplantation or the end of the study period varied 
TABLE I

DETAILS OF THE PATIENTS

\begin{tabular}{lrrr} 
& Total & Women & Men \\
\hline $\begin{array}{l}\text { No. of patients dialysed before } \\
\text { transplantation }\end{array}$ & 38 & 22 & 16 \\
$\begin{array}{l}\text { No. of patients receiving a renal } \\
\text { transplant }\end{array}$ & 31 & 16 & 15 \\
$\quad \begin{array}{l}\text { Successful } \\
\quad \text { Failure (rejection) }\end{array}$ & 26 & 14 & 12 \\
$\begin{array}{l}\text { No. of patients dialysed after } \\
\text { transplantation }\end{array}$ & 5 & 2 & 3 \\
$\quad 22$ & 8 & 14
\end{tabular}

between four and 260 days (average 79 days) and after transplantation between two and 48 days (average 18 days).

\section{DIALYSIS PROCEDURE}

The peritoneal dialysis procedure used was based on the method described by Maxwell et al (1959) and has been reported in detail by Cohen and Percival (1968). Using full aseptic precautions a catheter was introduced into the peritoneal cavity through the midline about 1 in. below the umbilicus. The catheter was anchored by a single purse string suture and surrounded by sterile dry gauze swabs and covered with a layer of Micropore surgical tape (3.M.Co.). The swabs were changed frequently but the catheter was only changed when it was obstructed. The dialysis solutions used were commercially available (Dialaflex, Allen and Hanburys), and heparin at a concentration of 1,000 units per litre was added before use. The dialysis fluid was introduced through a Dialaflex giving set (Allen and Hanburys) and drained after 30 minutes' retention into a collection bottle containing $1 \mathrm{ml}$ of $40 \%$ formaldehyde solution. Before and between exchanges the giving set spearheads and tip of the drainage tube were stored in $0.5 \%$ chlorhexidine in $70 \%$ alcohol. After dialysis the giving set was discarded and the peritoneal catheter sealed with a disposable plastic spigot.

\section{LABORATORY METHODS}

Each day a sample of the first dialysis effluent was examined from all patients. Ten to $15 \mathrm{ml}$ of the effluent was centrifuged at $1,500 \mathrm{rpm}$ for 15 minutes and the deposit was cultured. Gram-stained films of the deposit were examined only when the patient had symptoms of an infection and a quick result was needed.

Bacterial growth was identified by routine laboratory methods. Strains of Staph. aureus were phage typed and strains of Esch. coli were $O$ serotyped using a set of 11 standard $O$ antisera (Williams, Leigh, Rosser, and Brumfitt, 1965). Strains of Ps. aeruginosa were pyocine typed using the indicator strains of Gillies and Govan (1966) and $O$ serotyped using $O$ antisera produced in rabbits from 18 standard $O$ serotype strains supplied by Dr T. M. Parker, Public Health Laboratory, Colindale.

The antibiotic sensitivities of the infecting organisms u ere determined by the impregnated disc technique and a tube dilution method.
TREATMENT

When antibiotic treatment was required the drug wast always given in the dialysis fluid and in a few cases ora or parenteral therapy was also given.

The antibiotic concentration in the dialysis fluid varie $\bar{p}$ with the substance used: gentamicin was given in a con centration of 10 or $25 \mu \mathrm{g}$ per ml, cloxacillin ampicillin kanamycin, and cephaloridine at 25 or $50 \mu \mathrm{g}$ per miç and carbenicillin at $100 \mu \mathrm{g}$ per $\mathrm{ml}$. Amphotericin B was given in a concentration of 2.5 or $5 \mu \mathrm{g}$ per ml.

The treatment was usually given for five days but i $\overrightarrow{\mathrm{d}}$ some cases it was continued for as long as 14 days.

\section{CRITERIA OF INFECTION}

Peritoneal infection was considered to be present whe the patient complained of abdominal symptoms and ano organism was isolated from the dialysis effluent. N\& account was taken of the numbers of organisms present and a light growth was as significant as a heavy growthes The presence of staphylococci and streptococci in th\& effluent fluid in the absence of symptoms was considere $\Phi$ to be significant and treatment given only when the were found in two consecutive daily specimens. Th@ isolation of Gram-negative bacilli was invariably associated with severe abdominal symptoms and fever an treatment was given immediately.

\section{CRITERION OF CURE}

Treatment was considered successful where the organisrit was permanently eradicated from the dialysis effluen Reappearance of the same organism in the fluid within 72 hours of stopping treatment was taken to indicate a inadequate course of treatment and a second course was given. A recurrence of the infection after stoppingt treatment for more than 72 hours was regarded as failure of treatment.

\section{RESULTS}

INCIDENCE OF PERITONEAL INFECTION Twenty-tw $(58 \%)$ of the 38 patients dialysed before transplantation developed an infection and of the 22 patients who required short periods of dialysis after trans plantation nine $(41 \%)$ became infected. There was no significant difference in the incidence of infectios in men and women. Fifty per cent of the patients infected before transplantation also developed infeç tion after transplantation and three $(30 \%)$ of the uninfected patients became infected after transe plantation.

Thirty-four episodes of infection occurred in the 22 patients infected before transplantation, $1 \cdot T$ having a single episode and nine and two having tw and three episodes respectively. After transplant tion 14 episodes of infection occurred in the nire patients and four had a single episode, three had 


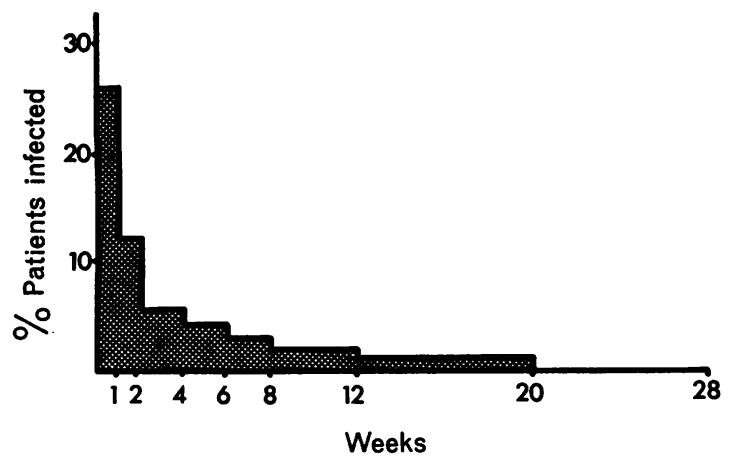

FIG. 1. Incidence of peritoneal infection related to length of dialysis.

two episodes, and two had three and four episodes respectively.

The greatest incidence of infection occurred in the first week of dialysis when almost $30 \%$ of the patients at risk became infected (Fig. 1). This incidence fell rapidly over the next four weeks to approximately $6 \%$.

The rate of infection in patients on dialysis before transplantation was 1.23 infections per 100 patient days but after transplantation the rate was much higher (4.17 infections per 100 days). In the seven patients not yet transplanted the rate was even lower ( 0.85 infections per 100 days) (Table II).

Although most patients developed an infection within one month of starting dialysis, these did not occur before the third day and three patients only developed an infection after 54, 71, and 129 days of dialysis. Of the uninfected patients, four were dialysed for $96,109,138$, and 157 days respectively.

INFECTING ORGANISMS Twenty-seven (79\%) of the infections occurring before transplantation were due to Gram-positive cocci (Table III). Staph aureus was isolated in 12 infections and Staph albus (coagulase negative) in 11 infections. After transplantation only six $(43 \%)$ of the 14 infections were caused by Gram-positive cocci.

Gram-negative bacilli were more frequent in the post-transplantation infections. Only five $(15 \%)$ of the infections before transplantation were due to Gram-negative bacilli.
TABLE III

INFECTING ORGANISMS IN 48 INFECTIONS

\begin{tabular}{lll} 
& $\begin{array}{l}\text { Before } \\
\text { Transplantation }\end{array}$ & $\begin{array}{l}\text { After } \\
\text { Transplantation }\end{array}$ \\
\hline No. of infections & 34 & 14 \\
$\begin{array}{l}\text { Gram-positive cocci } \\
\quad \text { Staph aureus }\end{array}$ & 12 & 2 \\
$\begin{array}{l}\text { Staph albus } \\
\text { Strept faecalis }\end{array}$ & 11 & 2 \\
Strept pneumoniae & 3 & -1 \\
Strept viridans & -1 & 1 \\
$\quad$ Total & 1 & $6(43 \%)$ \\
$\quad$ Gram-negative bacilli & $27(79 \%)$ & \\
Ps aeruginosa & & 2 \\
Prot mirabilis & 1 & 2 \\
Esch coli & 1 & 1 \\
Klebsiella sp & 2 & 1 \\
Alkaligenes sp & 1 & $7(50 \%)$ \\
$\quad$ Total & - & $1(7 \%)$ \\
Candida albicans & $5(15 \%)$ &
\end{tabular}

Infection due to Candida albicans was seen in three cases and the incidence was the same before and after transplantation.

SOURCE OF THE INFECTING ORGANISMS An organism apparently identical to the infecting organism had been isolated from another site on the patient before development of the infection in $22(46 \%)$ of the 48 infections (Table IV).

In 10 of the 14 infections caused by Staph aureus an organism of the same phage type had been isolated either from the nose or the skin around the dialysis catheter. With infections due to Staph albus it was more difficult to find the source but in four $(31 \%)$ of the 13 infections an organism with the same antibiotic sensitivity pattern had been isolated from the skin around the dialysis catheter.

In seven $(58 \%)$ of the 12 infections caused by Gram-negative bacilli an organism of the same serotype had been isolated from either the faeces, the skin around the catheter or a wound infection.

CARRIAGE OF ORGANISMS ON THE DIALYSIS CATHETER SITE The rate of carriage of bacteria on the skin around the dialysis catheter was almost twice as high after as before transplantation. One thousand and three swabs were examined from the 38 patients

TABLE II

INCIDENCE OF PERITONEAL INFECTION IN PATIENTS ON DIALYSIS

\begin{tabular}{|c|c|c|c|c|}
\hline & No. of Patients & $\begin{array}{l}\text { No. of Days } \\
\text { Dialysed }\end{array}$ & $\begin{array}{l}\text { No. of } \\
\text { Infections }\end{array}$ & $\begin{array}{l}\text { Incidence } \\
\text { per } 100 \text { Days }\end{array}$ \\
\hline $\begin{array}{l}\text { Before transplantation } \\
\text { After transplantation }\end{array}$ & $\begin{array}{l}38 \\
22\end{array}$ & $\begin{array}{r}2,748 \\
340\end{array}$ & $\begin{array}{l}34 \\
14\end{array}$ & $\begin{array}{l}1 \cdot 23 \\
4 \cdot 17\end{array}$ \\
\hline Total & 38 & 3,088 & 48 & 1.56 \\
\hline
\end{tabular}


TABLE IV

SOURCE OF INFECTING ORGANISM IN PERITONEAL INFECTION

\begin{tabular}{|c|c|c|c|}
\hline Orgarism & Total & \multicolumn{2}{|c|}{ Source of Infecting Organism } \\
\hline $\begin{array}{r}\text { Gram-positive cocci } \\
\text { Staph aureus }\end{array}$ & 14 & $10(71 \%)$ & Dialysis catheter site 6 , \\
\hline $\begin{array}{l}\text { Staph albus } \\
\text { Strept faecalis } \\
\text { Strept pneumoniae } \\
\text { Strept viridans }\end{array}$ & $\begin{array}{r}13 \\
3 \\
1 \\
2\end{array}$ & $\begin{array}{l}4(31 \%) \\
1 \\
0 \\
0\end{array}$ & $\begin{array}{l}\text { Dialysis catheter site } 4 \\
\text { Dialysis catheter site } 1 \\
\text { - }\end{array}$ \\
\hline Total & 33 & $15(45 \%)$ & \\
\hline $\begin{array}{r}\text { Gram-negative bacilli } \\
\text { Ps aeruginosa }\end{array}$ & 3 & 2 & Dialysis catheter site 1 \\
\hline Prot mirabilis & 3 & 2 & $\begin{array}{l}\text { Dialysis catheter site } 1 \\
\text { Wound } 1\end{array}$ \\
\hline Esch coli & 3 & 1 & $\begin{array}{l}\text { Faeces } 1 \\
\text { Dialysis catheter site } 1\end{array}$ \\
\hline $\begin{array}{l}\text { Klebsiella sp } \\
\text { Alkaligenes sp }\end{array}$ & $\begin{array}{l}2 \\
1\end{array}$ & $\begin{array}{l}1 \\
1\end{array}$ & Dialysis catheter site 1 \\
\hline Total & 12 & $7(58 \%)$ & \\
\hline Candida albicans & 3 & 0 & \\
\hline Total for all organisms & 48 & $22(46 \%)$ & \\
\hline
\end{tabular}

TABLE V

ORGANISMS ISOLATED FROM THE DIALYSIS CATHETER SITE SWABS

$$
\begin{array}{ll}
\text { Before } & \text { After } \\
\text { Transplantaticn } & \text { Transplantation }
\end{array}
$$

Organism

\begin{tabular}{lcc}
\hline $\begin{array}{l}\text { Gram-positive cocci } \\
\text { Staph aureus } \\
\text { Staph albus } \\
\text { Strept faecalis }\end{array}$ & 28 & 3 \\
$\quad$ Total & 41 & 10 \\
& 3 & 2 \\
$\begin{array}{l}\text { Gram-negative bacilli } \\
\text { Ps aeruginosa }\end{array}$ & $72(88 \%)$ & $15(45 \%)$ \\
$\begin{array}{l}\text { Prot mirabilis } \\
\text { Esch coli }\end{array}$ & 2 & \\
Klebsiella sp & 3 & 7 \\
Alkaligenes sp & 5 & 5 \\
$\quad$ Total & - & 1 \\
Candida albicans & $10(12 \%)$ & $18(55 \%)$ \\
& - & -
\end{tabular}

and 115 grew bacteria. The distribution of these organisms (Table V) was found to be very similar to that of the organisms causing peritoneal infection (of Table III).

TREATMENT The results of primary treatment of the 48 infections are shown in Table VI. Of the 34 infections before transplantation, $22(65 \%)$ responded to treatment. The cure rate after transplantation was similar and eight (57\%) of the infections were cleared by treatment.

Infections due to Gram-positive cocci were more successfully treated both before and after transplantation than those due to Gram-negative bacilli.
Two of the three infections caused by Candida albicans were cleared by treatment.

\section{DISCUSSION}

The incidence of peritoneal infection in patients on long-term dialysis is not well known as patientso requiring maintenance therapy for chronic renalo failure are usually managed on haemodialysis.

In a renal transplantation unit, however, long- $\overrightarrow{\vec{O}}$ term peritoneal dialysis has the advantage that 3 many patients can be treated in general wards by? the ordinary nursing staff without a large capital? expenditure. The technique is simple and provided certain precautions are taken side effects can be reduced to a minimum.

The incidence of infection following short-term dialysis for less than 72 hours is well known. Odel, Ferris, and Powers (1950) reviewed the literature between 1923 and 1948 and found that $47 \%$ of the patients had become infected. Since then the use of a smaller catheter and a closed system of drainage has undoubtedly reduced the incidence of infection, $\mathbb{N}$ and recent studies have shown an incidence of $N$ between $4 \%$ and $12 \%$ (Boen et al, 1964; Thomson, N Buchanan, Doak, and Peart, 1964; Stewart, Tuckwell, Sinnett, Edwards, and Whyte, 1966; Ribot, Jacobs, Frankel, and Bernstein, 1966). Schwartz, Kallmeyer, Dunea, and Kark (1967) found that no cases of peritonitis occurred when he replaced a large catheter by a small one and limited theperiod of dialysis to 72 hours. Lasker et al (1965) found that 12 of 13 patients on long-term dialysis? developed at least one episode of infection. Cohen 2 
TABLE VI

RESULTS OF ANTIBIOTIC TREATMENT ACCORDING TO INFECTING ORGANISM

$\begin{array}{llll}\text { Before Transplantation } & \text { After Transplantation } \\ \text { No. } & \text { Nure } & \text { No. Cure }\end{array}$

Organism

$$
\begin{gathered}
\text { Gram-positive cocci } \\
\text { Staph aureus } \\
\text { Staph albus } \\
\text { Strept faecalis } \\
\text { Strept pneumoniae } \\
\text { Strept viridans } \\
\text { Total } \\
\text { Gram-negative bacilli } \\
\text { Ps aeruginosa } \\
\text { Prot mirabilis } \\
\text { Esch coli } \\
\text { Klebsialla sp } \\
\text { Alkaligenes sp } \\
\text { Total } \\
\text { Candida aljicans }
\end{gathered}
$$

Total for all organism;
12

-

27

1
1
2
1
-
5
2

and Percival (1968) found that of 27 patients awaiting renal transplantation who were dialysed for more than two months, only three remained clear of infection.

In this study of 38 patients the incidence of infection in patients dialysed before transplantation was $58 \%$ and after transplantation $41 \%$. Infection did not usually occur before the third day of dialysis and the greatest attack rate of infection $(26 \%)$ was seen in the first week (Fig. 1). All the patients at this time were severely uraemic and the susceptibility of such patients to infection is well known. The attack rate after the eighth week of dialysis was low and three patients did not develop infection until the eighth, 11th, and 19th week of dialysis. Infection, however, was not always related to the length of dialysis, and four patients did not become infected even though they were dialysed for $14,16,20$, and 23 weeks.

The frequency of peritoneal infection before renal transplantation has fallen significantly since the introduction of long-term peritoneal dialysis to the Renal Unit at St Mary's Hospital. Between 1965 and 1966 the rate of infection per 100 patient days of dialysis fell from 3.12 to 1.29 (Cohen and Percival, 1968), and in this study in 1967 and 1968 to $1 \cdot 23$. In the patients still awaiting renal transplantation it has fallen even lower to $\mathbf{0 \cdot 8 5}$.

As routine bacteriological screening of patients was carried out it was often possible to find a probable source for the infecting organism. The major source of infection was the skin around the dialysis catheter and the commonest infecting organisms, Staph aureus and Staph albus, were those most frequently isolated from this site (cf Table V

\begin{tabular}{lll}
$8(67 \%)$ & 2 & 1 \\
$8(73 \%)$ & 2 & 2 \\
2 & -1 & 1 \\
\hline 1 & 1 & 1 \\
$19(70 \%)$ & 6 & $5(83 \%)$ \\
1 & 2 & 0 \\
0 & 2 & 0 \\
2 & 1 & 0 \\
0 & 1 & 1 \\
- & 1 & 1 \\
$3(60 \%)$ & 7 & $2(29 \%)$ \\
1 & 1 & 1 \\
$22(65 \%)$ & 14 & $8(57 \%)$
\end{tabular}

and III). Despite prophylactic treatment with chlorhexidine and nystatin dusting powder organisms were isolated from approximately $10 \%$ of swabs taken from the skin around the dialysis catheter. These findings confirm the earlier work of Cohen and Percival (1968) in this unit and the view of Montgomerie et al (1968), although they conflict with those of Schwartz et al (1967), who found all the infecting organisms to be of enteric origin, and with the transmural migration theory of Schweinburg, Seligman, and Fine (1950).

Although infections caused by Gram-negative bacilli were usually associated with severe symptoms, those caused by Gram-positive cocci, especially Staph albus, were frequently asymptomatic. In these cases the focus of infection was usually the catheter tip where a plug of fibrin provided a constant source of bacteria and replacement of the catheter cured the infection. When infection was manifest clinically, the dialysis fluid was usually cloudy and technical difficulties were sometimes encountered due to obstruction to the overflow of fluid by fibrinous or purulent exudate. Treatment of the infection by giving intraperitoneal antibiotics frequently resulted in an improvement in drainage, as was observed by Burns et al (1962).

The concentration of antibiotic given in the dialysis fluid was chosen so that an adequate serum level could be achieved and the sensitivity of the infecting organism exceeded by at least five-fold (Barber and Garrod, 1963). The results of treatment were considerably better with Gram-positive infections than with Gram-negative infections (Table VI), especially following renal transplantation. Peritoneal infection after renal transplantation caused 
by Gram-negative bacilli was frequently associated with severe complications, such as ureteric necrosis or poor function of the renal transplant, and the prognosis in these patients was poor; four of the six patients died as a direct result of the infection. Gram-positive infections, however, were rarely associated with postoperative complications.

Peritoneal dialysis provides an easy way to maintain patients with chronic renal failure, especially those who will eventually receive renal transplants. The incidence of infection can be reduced by prophylactic treatment of the skin around the dialysis catheter but it is still high. Many patients, however, can be dialysed for several months without developing an infection.

I would like to thank Miss C. Whittaker and the staff of the Routine Bacteriology Laboratory for help with examining the dialysis specimens, and Professor W. S. Peart for allowing me to carry out this study on patients under his care.

\section{REFERENCES}

Barber, M., and Garrod, L. P. (1963). Antibiotic and Chemotherap $\sqrt{\overline{\sqrt{n}}}$ p. 229. Livingstone, Edinburgh and London.

Boen, S. T., Mion, C. M., Curtis, F. K., and Shilipeter, G. (1964? Trans. Amer. Soc. artif. intern. Org., 10, 409.

Burns, R. O., Henderson, L. W., Hager, E. B., and Merrill, J. (1962). New Engl. J. Med., 267, 1060.

Cohen, S. L., and Percival, A. (1968). Brit. J. med. 1, 409.

Gillies, R. R., and Govan, J. R. W. (1966). J. Path. Bact., 91, 339

Lasker, N., Shalhoub, R., Habibe, O., and Passarotti, C. (1965) Ann. intern. Med., 62, 1147.

Maxwell, M. H., Rockney, R. E., Kleeman, C. R., and Twiss, M. RD (1959). J. Amer. med. Ass., 170, 917.

Montgomerie, J. G., Kalmanson, G. M., and Guze, L. B. $(1968)$ Medicine (Baltimore), 47, 1.

Odel, H. M., Ferris, D. O., and Powar, M. H. (1950). Amer. J. Med 9, 63. Ribot, S., Jacobs, M. G., Frankel, H. J., and Bernstein, A. (1966 N
Amer. J. med. Sci., 252, 505.

Schwartz, F. D., Kallmeyer, J., Dunea, G., and Kark, R. M. (1967ir J. Amer. med. Ass., 199, 79.

Schweinburg, F. B., Seligman, A. M., and Fine, J. (1950). New Engఱ్ఝ J. Med., 242, 747.

Stewart, J. H., Tuckwell, L. A., Sinnett, P. F., Edwards, K. D. G을 and Whyte, H. M. (1966). Quart. J. Med., 35, 407.

Thomson, W. B., Buchanan, A. A., Doak, P. B., and Peart, W. S (1964). Brit. med. J., 1, 932.

Williams, J. D., Leigh, D. A., Rosser, E. ap I., and Brumfitt, (1965). J. Obstet. Gynaec. Brit. Cwlth., 72, 327. 